Agata Gawlak

Magda Matuszewska

Paulina Szuba (paulina.r.szuba@doctorate.put.poznan.pl)

Zakład Architektury Usługowej i Mieszkaniowej, Instytut Architektury, Urbanistyki

i Ochrony Dziedzictwa, Wydział Architektury, Politechnika Poznańska

\title{
Jakość przestrzeni architektonicznej dedykowanej ochronie zdrowia a potrzeby mieszkańców w kontekście założeń idei healthy cities na przykładzie Poznania
} The Quality of Healthcare Architecture and its Relationship to Public Health and Citizens' Needs in the Context of Healthy Cities Principles on the Example of Poznan

\section{Streszczenie}

Celem niniejszego artykułu jest przedstawienie procesu wdrażania strategii healthy cites w kontekście poprawy jakości przestrzeni architektonicznej na przykładzie miasta Poznania oraz próba dokonania oceny spełnienia założeń programowych Stowarzyszenia Zdrowych Miast Polskich i idei healthy cities, jak również ewaluacja zmian w przestrzeni dedykowanej ochronie zdrowia. Obserwowany obecnie duży wzrost wymagań społecznych związanych z opieką zdrowotną, w tym wysoką jakością przestrzeni, pozwala zauważyć zależność pomiędzy jakością rozwiązań architektonicznych, funkcjonalno-przestrzennych w szpitalu a procesem zdrowienia pacjenta.

Słowa kluczowe: zdrowe miasta, architektura służby zdrowia, ochrona zdrowia, Poznań

\begin{abstract}
This article aims to describe in more detail the implementation of the Healthy Cities strategy in the context of the improved quality of the architectural space based on the example of Poznan, and to assess whether the assumptions of the programme of the Polish Association of Healthy Cities and the ideas of Healthy Cities are met and to evaluate the changes in space dedicated to health care. At present, there is a growing social demand for health care, in this a demand for high quality space, which allows us to observe that there are interdependencies between the quality of architectural functional and spatial solutions applied in hospitals and the patient's recovery process.
\end{abstract}

Keywords: healthy cities, healthcare architecture, health care, Poznan 


\section{WSTĘP}

Miasto Poznań to jeden z najsilniejszych ośrodków gospodarczych w Polsce, ze zróżnicowaną, dobrze rozwiniętą i zbilansowaną gospodarką miejską, zdominowaną przez usługi. Dzięki coraz lepszym warunkom do życia, promowaniu zdrowego stylu życia i dobrej opiece medycznej, w ciągu ostatnich 5 lat przewidywana długość życia poznaniaków i poznanianek wydłużyła się o prawie 4 lata. Tendencję tą obserwuje się od ponad 25 lat $^{1}$. Jest to odzwierciedlenie globalnej tendencji i mieści się w bieżących prognozach. Szacuje się bowiem, że w Polsce w okresie kolejnych 30 lat liczba ludności powyżej 60. roku życia zwiększy się o ok. 40\% (II. 1).

Jak ocenia prof. dr hab. Ryszard Cichocki, dyrektor Centrum Badania Jakości Życia, wysoka jakość życia mieszkańców Poznania, to jeden z najważniejszych priorytetów strategicznych miasta². Utworzone przez Miasto Poznań i Uniwersytet Adama Mickiewicza Centrum Badania Jakości Życia ${ }^{3}$ prowadzi systematyczne badania nad stanem i zmianami jakości życia. Oprócz badań prowadzonych przez Centrum, popularne jest organizowanie licznych konsultacji społecznych oraz spotkań ze specjalistami. Dotyczą one najczęściej zmian w przestrzeni architektonicznej, przyjęcia stosownych uchwał, układania strategii i programów. Co istotne, w dokumentach tych zawiera się wytyczne formalno-prawne, które odnoszą się bezpośrednio do jakości przestrzeni, w tym budynków służby zdrowia. Warto przywołać dla przykładu podpisanie nowej Strategii Rozwoju Miasta Poznania 2020+ w styczniu 2017 roku4. Przy układaniu nowej strategii (ostatnia została podpisana w 2013 roku) uznano, że miasto jest tworzone przez mieszkańców i dla mieszkańców, a ich potrzeby i spostrzeżenia, na równi z wiedzą ekspercką, są wykorzystywane do przygotowania kluczowych zapisów.

Jednym z głównych celów strategicznych Poznania jest podniesienie świadomości prozdrowotnej wśród mieszkańców oraz dostępności do świadczeń zdrowotnych, co wyraża się w sformułowanych celach operacyjnych. W aglomeracji poznańskiej, liczącej 647018 mieszkańców, pracuje tylko 32 lekarzy i 13 pielęgniarek na 10 tys. mieszkańców5

Miasto Poznań jest organem tworzącym dla trzech podmiotów zapewniających leczenie stacjonarne oraz jednego zakładu leczenia ambulatoryjnego. W ramach pierwszego celu operacyjnego dąży się zatem do poprawy infrastruktury miejskich szpitali poprzez rozbudowę i modernizację obiektów, a także zakup niezbędnego sprzętu medycznego. Mimo że według danych z 2013 roku poznaniacy ocenili dostępność usług medycznych jako przeciętną, należy odnotować, iż Strategia Rozwoju Miasta Poznania do roku 2030 zawiera m.in. plany rozbudowy sieci obiektów dedykowanych służbie zdrowia i innych obiektów powiązanych.

Dzięki włączeniu się Poznania w 2001 roku do Stowarzyszenia Zdrowych Miast Polskich (potwierdzonego w 2000 roku przez Światową Organizację Zdrowia o spełnianiu wymogów stawianych przez WHO narodowym sieciom Zdrowych Miast w Europie), wdrożono politykę zdrowotną, której priorytetami są między innymi: promocja zdrowia i zdrowego stylu życia, dostęp do wysokiej jakości usług społecznych, zdrowe środowisko miejskie, a przestrzeń architektoniczna dedykowana służbie zdrowia w Poznaniu staje się coraz bardziej przyjazna i sprzyjająca mieszkańcom. 


\section{SZPITALE. JAKOŚĆ ŻYCIA W MIEŚCIE}

\subsection{PRZESTRZEŃ ARCHITEKTONICZNA A ZDROWIE}

Przestrzeń architektoniczna dedykowana obiektom ochrony zdrowia powinna być rozumiana zarówno jako przestrzeń wewnątrz i wokół budynku, jak i pomiędzy budynkami o tożsamej funkcji w mieście ${ }^{6}$. Oznacza to nie tylko budynek z przynależną infrastrukturą, lecz także przestrzeń publiczną, z której korzystają nie tylko sami użytkownicy szpitala (pacjenci, personel czy odwiedzający), ale również mieszkańcy miasta.

Szpital w kontekście rozwiązań funkcjonalno-przestrzennych traktowany jest jako element wspierający hospitalizację oraz wpływający na zachowania i komfort wszystkich jego użytkowników: pacjentów, personelu oraz osób odwiedzających. Architektura szpitali nadal jednak podlega stereotypom w postrzeganiu jej przez mieszkańców miast; budynki te kojarzone są wciąż z izolacją. Wpływa na to m.in. lokalizowanie szpitali poza miastem, co utrudnia dojazd pacjentom i osobom odwiedzającym, ich wielkość gdyż wiele obiektów projektowano na kilkaset łóżek, co stwarza wrażenie „maszyn do leczenia”, bezosobowo obsługujących pacjentów oraz proces unifikacji w zakresie formy architektury, ponieważ budynki szpitali często pozbawione są detalu, posiadają płaskie w odbiorze fasady z rytmem otworów okiennych, wokół brak jest atrakcyjnie zaprojektowanych terenów zielonych z przyszpitalnymi ogrodami czy dziedzińcami. Taka architektura i przestrzeń wokół potęgują stres, uczucie zagubienia i wyobcowania pacjentów. Natomiast z badań prowadzonych przez prof. ZUT M. Czyńskiego7 wynika, iż główne oczekiwania pacjenta względem budynku szpitala to przede wszystkim: skuteczne leczenie (diagnoza, zabiegi, rehabilitację), ale również troskliwa pielęgnacja w okresie hospitalizacji oraz godne i przyjazne warunki pobytu.

Jakość architektury dedykowanej ochronie zdrowia koreluje z jakością świadczeń zdrowotnych (personel, pacjenci, rodzina). Przestrzeń architektoniczna kształtuje interakcję terapeutyczną (...), a zachowania osoby będącej przedmiotem terapii oraz zachowania osób sterujących terapią stanowią wraz z przestrzenią architektoniczną całość interakcyjną, której efektem są określone skutki zdrowotne, mentalne i społeczne ${ }^{8}$.

Częstym elementem wspomagającym leczenie i skutecznie realizującym postulaty healing environment jest zieleń w strukturze budynku i tzw. ogrody terapeutyczne. Stanowią one środowisko zarówno dla terapii biernej, jak i czynnej, gdzie indywidualnie dobrane przez terapeutów zajęcia, prowadzone w specjalnie przystosowanych do potrzeb osób niepełnosprawnych założeniach ogrodowych, podnoszą sprawność pacjentów, redukują napięcie i stres. 


\subsection{EBD JAKO STRATEGIA W PROJEKTOWANIU SZPITALI}

Projektowanie architektoniczne obiektów służby zdrowia, zgodnie z teorią evidence-based design ${ }^{9}$, opiera się na wynikach wiarygodnych badań naukowych. Rozwój evidence-based design został zainspirowany evidence-based medicine i spowodowany był chęcią uzyskania maksymalnych korzyści dla indywidualnego pacjenta. Projektowanie w EBD stoi w opozycji do konwencjonalnego projektowania przestrzeni w oparciu o wiedzę i intuicję. W centrum zainteresowań EBD jest pacjent, jego poczucie bezpieczeństwa i jego proces zdrowienia, natomiast nie mniej istotny jest czynnik związany z pracą personelu medycznego, jego komfortem, wydajnością i również poczuciem bezpieczeństwa.

Wieloletnie badania naukowe potwierdzają jednoznacznie wpływ zastosowanych rozwiązań architektonicznych, w tym funkcjonalno-przestrzennych, na proces zdrowienia pacjentów, ich komfort ${ }^{10}$ oraz samopoczucie i wydajność personelu ${ }^{11}$.

Świadome korzystanie z osiągnięć naukowych przez osoby zarządzające w ochronie zdrowia oraz w planowaniu na poziomie również legislacyjnym, może stać się przyczynkiem do lepszego wykorzystania potencjału, jaki niesie za sobą zarówno sam budynek, jak i otaczający go teren. Ma to szczególne znaczenie w czasach bardzo dużych i świadomych wymagań pacjentów oraz personelu względem opieki medycznej, w tym względem komfortu pobytu w szpitalu.

W związku z powyższym również na uczelniach prowadzi się badania naukowe ${ }^{12}$, których wyniki implementuje się później do strategii projektowania. Jednym z przykładów mogą być badania przeprowadzone w 2011 r. na terenie Specjalistycznego Zespołu Opieki Zdrowotnej nad Matką i Dzieckiem im. B. Krysiewicza w Poznaniu ${ }^{13}$, których celem była analiza wpływu rozwiązań funkcjonalno-przestrzennych w szpitalu pediatrycznym na jego funkcjonowanie, ze szczególnym uwzględnieniem satysfakcji pacjenta i jego możliwości adaptacyjnych oraz relacji pomiędzy wizualną jakością przestrzeni publicznej w szpitalach a poziomem zadowolenia, stresu i poczuciem bezpieczeństwa jego użytkowników. Badania prowadzono wśród mieszkańców m. Poznania, jak również bezpośrednio wśród pacjentów szpitala. Udowodniono, iż rozwiązania funkcjonalno-przestrzenne izby przyjęć wpływają istotnie na samopoczucie, bezpieczeństwo oraz satysfakcję pacjentów. Udowodniono również, że satysfakcja pacjentów warunkowana jest rozwiązaniami architektonicznymi w przestrzeni szpitala oraz jest determinowana przez zmienne socjodemograficzne, takie jak: wiek, płeć, czas przebywania w izbie przyjęć itd. Ocena jakości przestrzeni, jak i projektowanych udogodnień jest zależna również od takiej zmiennej jak czas oczekiwania pacjenta na rejestrację. Efektem przeprowadzonych badań dla szpitala im. B. Krysiewicza było przeprowadzenie modernizacji przestrzeni izby przyjęć.

Innym przykładem może być projekt rozbudowy szpitala pediatrycznego przy ul. Spornej w Poznaniu w ścisłym centrum miasta ${ }^{14}$, jako kontynuacja przestrzenna i funkcjonalna w kontekście historycznej zabudowy. Projekt koncepcyjny, poza realizacją założeń programowych dla budynku, ma na celu zachowanie ładu przestrzennego w tej części miasta. 
W ostatnich latach powstało wiele prac studyjnych, które w sposób wariantowy proponowały rozwiązania przestrzenne, których celem było m.in. poprawienie jakości przestrzeni centrum miasta.

\section{IDEA HEALTHY CITIES}

Projekt healthy cities, globalny ruch zapoczątkowany i promowany przez WHO, angażuje rządy wielu państw poprzez zobowiązania polityczne, innowacyjne projekty i planowanie partnerskie. Członkami WHO European Healthy Cities Network jest obecnie 100 głównych miast i 1400 partnerskich ${ }^{15}$. Głównym celem organizacji European Healthy Cities Network jest zwiększenie świadomości zdrowotnej na poziomie socjalnym, ekonomicznym oraz promowanie jej w programach rządowych (II. 2). Lokalne władze posiadają największe i unikalne możliwości, aby chronić swoich mieszkańców, uświadamiać ich, promować zdrowe nawyki i zachęcać do zdrowego trybu życia.

Healthy cities, promując wszechstronne i systematyczne działanie, wyszczególnia zagadnienia powiększających się nierówności między zdrowym trybem życia i miejskim ubóstwem oraz socjalne, ekonomiczne i środowiskowe uwarunkowania zdrowotne.

Jak twierdzi Światowa Organizacja Zdrowia, w założeniach projektowych nie chodzi wyłącznie o sektor zdrowotny. Działanie ma na celu poprawę sytuacji ekonomicznych, gospodarczych i rozwoju państw ${ }^{16}$.

Zdrowe miasto ${ }^{17}$ to organizm, który ciągle kreuje i ulepsza fizyczne i socjalne aspekty środowiska oraz eksponuje działania wspierające jego prawidłowe funkcjonowanie, wykorzystując przy tym maksimum potencjału. To najbardziej znany sposób na rozpowszechnienie działań prozdrowotnych. Program zakłada długoterminową, rozwojową inicjatywę, mającą na celu uwrażliwienie globalnych decydentów na kwestię promowania zdrowia i strategii jego ochrony oraz zrównoważonego rozwoju. Healthy city ma w obowiązku stworzyć prozdrowotne środowisko, osiągnąć dobrą jakość życia dla mieszkańców, zapewnić podstawowe warunki sanitarne i higieniczne oraz zapewnić dostęp do opieki medycznej. Ustalono różne priorytety dla każdego kontynentu, kraju i miasta, lecz łączy je jeden cel: ulepszenie i przedłużenie życia ludzi i stworzenie uzdrawiającego środowiska.

\subsection{EWALUACJA PROGRAMÓW HEALTHY CITIES}

Ewaluacja programów healthy cities dowiodła skuteczności i zwiększeniu świadomości o zdrowiu i ochronie środowiska. Największe osiągnięcia programu to zobowiązania lokalnych społeczności, jasny przekaz, szerokie spektrum interesantów, proces instytuowania programu.

Na świecie prowadzi się wiele badań mających na celu ocenę sposobów wdrażania idei healthy city. Wartą uwagi jest działalność londyńskiej ARUP ${ }^{18}$ W publikacji Cities Alive 
- Towards a Walking World zwrócono uwagę na istotną kwestię, która jest jednym z fundamentów prawidłowego rozwoju i działania miasta. Zauważono, że priorytetową misją musi stać się lepsza organizacja przestrzenna miast. Do 2030 roku około $70 \%$ ludzi będzie zamieszkiwało tereny zurbanizowane. Od jakości życia ludzi je zamieszkujących będzie zależeć globalna przyszłość. Obserwuje się, że władze lokalne, a nie państwowe, mają większe predyspozycje i możliwości do wprowadzenia istotnych zmian w zakresie zmierzenia się problemami klimatycznymi, rozwoju gospodarki prowadzącego do dobrobytu gospodarczego oraz zapobieganiu ubóstwu. Autorzy piszą o dużym wpływie mediów i uświadamiania mieszkańców poprzez konsultacje społeczne, przedstawianie projektów i proponowanie rozwiązań ku polepszeniu warunków i jakości życia. Autorzy zwracają dużą uwagę na istotę promowania aktywnego stylu życia. Według Światowej Organizacji Zdrowia brak aktywności fizycznej jest czwartym czynnikiem powodującym zwiększenie statystyk śmiertelności w skali globalnej. Ostatnie badania przeprowadzone przez Nike ${ }^{19}$ świadczą, że jest to coraz bardziej pogłębiająca się tendencja globalna. Fizyczna aktywność spadła o 32\% w ostatnich 44 latach w Stanach Zjednoczonych Ameryki i aż o 45\% w ciągu tylko 18 lat w Chinach. Według badań spadek aktywności świadczy o przystosowaniu kontekstu urbanistycznego i infrastruktury nie do pieszych, lecz posiadaczy samochodów i innych pasywnych form transportu. Promowanie aktywności fizycznej wśród młodych pokoleń poprzez programy zawarte na przykład w porozumieniu healthy cities oraz inne kampanie i edukację wykształci aktywne społeczeństwo przyszłości.

\subsection{POZNAŃ A HEALTHY CITIES}

Miasto Poznań przystąpiło do projektu po raz pierwszy w $1991 \mathrm{r}^{20}$. Miasto realizowało II Fazę w latach 1993-1997. Pomimo że Rada Miasta Poznania zadeklarowała wolę przystąpienia do III Fazy, trwającej w latach 1998-2002, ze względów proceduralnych okazało się to niemożliwe (zbyt długi okres rozpatrywania przez WHO otrzymanych dokumentów). Od 2005 roku Miasto Poznań współpracowało z WHO w ramach IV Fazy Projektu Zdrowe Miasta $^{21}$, która zakończyła się w 2008 r.

V Faza projektu została wprowadzona w latach 2009-2013. Obejmowała trzy główne tematy: środowisko opiekuńcze i wspierające, zdrowy styl życia, zdrowe środowisko miejskie. Kluczowymi kwestiami wdrożonymi w V Fazie było polepszenie warunków dla mieszkańców, poczynając od świadczenia usług wczesnego dzieciństwa, po wsparcie dla seniorów; program wspierania zdrowego trybu życia oraz budowanie zdrowego środowiska miejskiego. Poprzez inicjację zdrowego planowania przestrzennego przyjaznego dla mieszkańców oraz wprowadzanie polityki wzmacniającej kompetencje zdrowotne mieszkańców społeczeństwo otrzymuje wsparcie rozwoju wysokiej jakości usług zdrowotnych dostępnych dla wszystkich.

Oprócz wdrażania faz projektu Zdrowych Miast, Wydział Rozwoju Miasta Poznań zobligowany jest do opracowywania strategii rozwoju miasta. W strategii na rok 2030 wskazano cele 
strategiczne, pośrednie i główne dotyczące świadomości prozdrowotnej, które składają się na całościową wizję miasta Poznania, jako miasta metropolitalnego o silnej gospodarce i wysokiej jakości życia, opierającego swój rozwój na wiedzy. Celem głównym programu jest zapewnienie możliwości zachowania przez mieszkańców zdrowia fizycznego i psychicznego. Program „Zdrowy Poznań"22 jest realizowany systematycznie od 2010 r. i przyczynia się do promocji zdrowia poprzez działania na rzecz zwiększenia świadomości prozdrowotnej indywidualnej i grupowej mieszkańców. Jego nadrzędnym celem jest poprawa jakości życia mieszkańców miasta, co koresponduje z podnoszeniem atrakcyjności przestrzeni i architektury miasta.

Pośród celów operacyjnych omawianych w Strategii Rozwoju Miasta Poznania do roku $2030^{23}$ wymienia się poprawę jakości opieki zdrowotnej w mieście poprzez rozwój miejskich placówek ochrony zdrowia. Dokument wskazuje również kluczowe projekty i przedsięwzięcia w realizacji celów operacyjnych w latach 2014-2030. W ramach celów operacyjnych dąży się do poprawy infrastruktury miejskich szpitali poprzez inwestycje w zakresie rozbudowy i modernizacji obiektów, a także zakup niezbędnego sprzętu medycznego. W ich skład wchodzi m.in. zapewnienie właściwej infrastruktury technicznej szpitala - standaryzacja ZOZ Poznań-Jeżyce oraz ZOZ (Poznań ul. Szwajcarska) czy dobudowa skrzydła do budynku Zakład Opiekuńczo-Leczniczy i Rehabilitacji Medycznej przy ul. Mogileńskiej (na 80 miejsc). Planuje się również budowę takich obiektów, jak: Centrum Zdrowia Psychicznego (na 60 miejsc), nowego obiektu dla filii w Owińskach (na 90 osób) oraz partycypację Miasta w budowie Zachodniego Centrum Chorób Serca i Naczyń w Poznaniu ${ }^{24}$.

W świetle przedstawionych parametrów regionu i zmian w strukturze demograficznej miasta Poznania istnieje potrzeba nieustannego poprawiania jakości architektury służby zdrowia.

Obecnie obserwuje się duży wzrost wymagań społecznych związanych z opieką zdrowotną, a poza nowoczesnymi metodami leczenia oczekuje się również wysokiej jakości przestrzeni, w której ten proces leczenia się odbywa. Istnieje zależność pomiędzy jakością rozwiązań architektonicznych, funkcjonalno-przestrzennych w szpitalu a procesem zdrowienia pacjenta. Rosnąca świadomość społeczna jest jednym z bodźców do weryfikacji ogólnie pojmowanej jakości służby zdrowia i ewaluacji przestrzeni architektonicznej jej dedykowanej.

Reakcją na tę potrzebę są nowe inwestycje w obszarze architektury służby zdrowia, realizowane w skali miasta i województwa. Najnowszą z nich jest rozbudowa Wielkopolskiego Centrum Onkologii w Poznaniu. Poznański Oddział Stowarzyszenia Architektów Polskich SARP ogłosił konkurs na opracowanie koncepcji architektoniczno-urbanistycznej obejmującej nowy budynek o funkcji ambulatoryjnej, zabiegowo-diagnostycznej wraz z garażem podziemnym ${ }^{25}$. Projektowany budynek ambulatoryjny ma stanowić rozwinięcie funkcjonalne istniejącego Centralnego Bloku Operacyjnego projektu wykonanego przez Pracownię Architektoniczną Ewy i Stanisława Sipińskich w 1998 r.

Wkrótce powinien zostać otwarty przetarg na budowę kolejnej inwestycji: Wielkopolskiego Centrum Zdrowia Dziecka (projekt: Industria Project z Gdańska). WCZD powstanie przy ulicy Wrzoska w Poznaniu i będzie największym nowo wybudowanym szpitalem pediatrycznym 
w Polsce (7 kondygnacji, ponad 30 tysięcy metrów kwadratowych powierzchni użytkowej, 354 łóżka - wszystkie w jednoosobowych salach z odrębnym węzłem sanitarnym). Inwestycja finansowana będzie ze środków Wielkopolskiego Programu Operacyjnego (WRPO 2014+), z budżetu województwa oraz budżetu państwa, a jej ukończenie przewiduje się na koniec 2020 roku.

Inną bieżącą inwestycją jest rozbudowa Szpitala im. prof. Stefana Tytusa Dąbrowskiego w Puszczykowie, który zyska nowy blok operacyjny o powierzchni 2 tysięcy metrów kwadratowych powierzchni użytkowej, mieszczący 5 nowoczesnych sal operacyjnych i centralną sterylizatornię, oraz o szyb windowy, który ma usprawnić komunikację wewnątrz placówki i poprawi warunki pracy personelu ${ }^{26}$. Nowy blok operacyjny powstaje również przy szpitalu MSWiA w Poznaniu. Autorem projektu architektonicznego jest Pracownia Projektowa Meritum z Chrzanowa ${ }^{27}$. Poprzez realizację wymienionych założeń dąży się do zwiększenia dostępności oraz jakości świadczeń zdrowotnych. Ponadto w Strategii Rozwoju Miasta Poznania do roku 2030 wyróżniono działania z zakresu profilaktyki i promocji zdrowia, które mają przyczynić się zapobieżeniu występowania zachorowań i uzależnień. W tym celu zakłada się realizację miejskich programów wspierających obszary dotyczących Ochrony Zdrowia Psychicznego, Profilaktyki i Rozwiązywania Problemów Alkoholowych (w tym prowadzenie Ośrodka dla Nietrzeźwych), Przeciwdziałania Narkomanii. Wskazuje się również założenia realizacji programów zdrowotnych z zakresu profilaktyki m.in. kardiologicznej, onkologicznej, cukrzycy, otyłości, grypy. Planuje się też prowadzenie innych działań profilaktycznych i promujących zdrowie, w tym m.in. konferencje ${ }^{28}$.

\section{PODSUMOWANIE}

W artykule przedstawiono aspekty dotyczące jakości architektury służby zdrowia, odnosząc się do idei healthy cities, na przykładzie nowych strategii dla rozwoju m. Poznania. Zmiany zaobserwowane w podejściu do realizowanych koncepcji odzwierciedlają ogólne tendencje, których działania ukierunkowane są na poprawę jakości życia w mieście. Szczególną uwagę zwrócono na przestrzeń budynków ochrony zdrowia w mieście, jakimi są szpitale.

Wskazano, iż w tworzeniu strategii dla miast, a w konsekwencji w projektowaniu architektonicznym obiektów ochrony zdrowia słusznym jest dążenie do uzyskania najnowocześniejszych pod względem technicznym i technologicznym rozwiązań projektowych, którym zawsze musi towarzyszyć troska o samopoczucie pacjenta, traktowanego jako podmiot działań twórczych architekta. Współcześnie architektura przychodni, szpitali (ogólnych i specjalistycznych), klinik, sanatoriów i obiektów wypoczynkowych (uzdrowiskowych) oraz domów opieki dla osób starszych ulega znaczącym zmianom ze względu na postęp naukowy, wydłużenie życia i podniesienie jego jakości, zwiększenie dostępności i specjalizację usług medycznych.

Uzasadnieniem jest wieloaspektowa relacja pomiędzy środowiskiem zbudowanym a stanem psychofizycznym i psychospołecznym człowieka, która w szczególny sposób przejawia się w projektowaniu budynków ochrony zdrowia. 
30

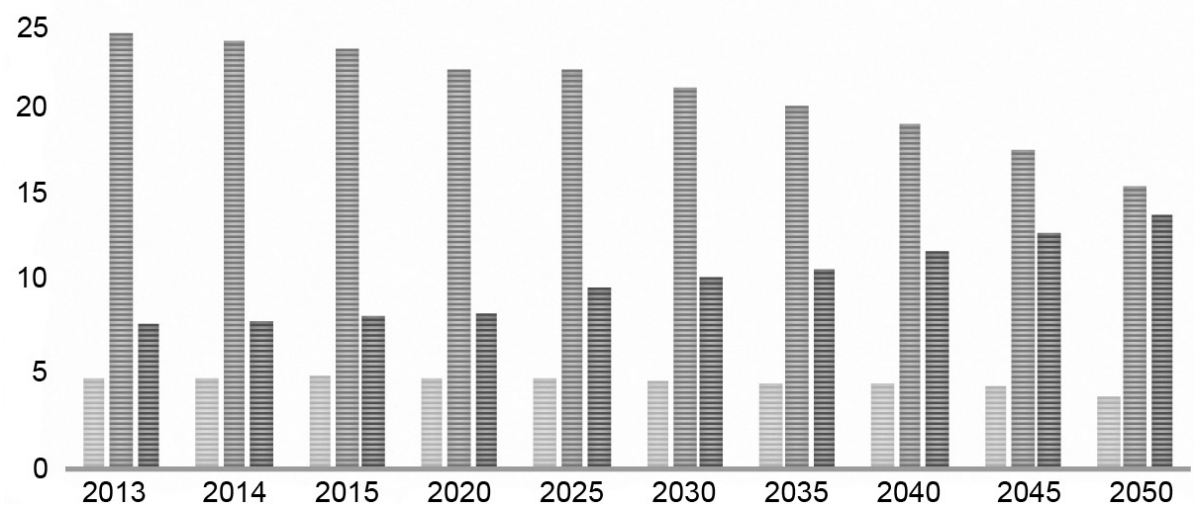

II. 1. Wykres prognozy liczby ludności w Polsce na podstawie badań GUS (autor: Agata Gawlak)

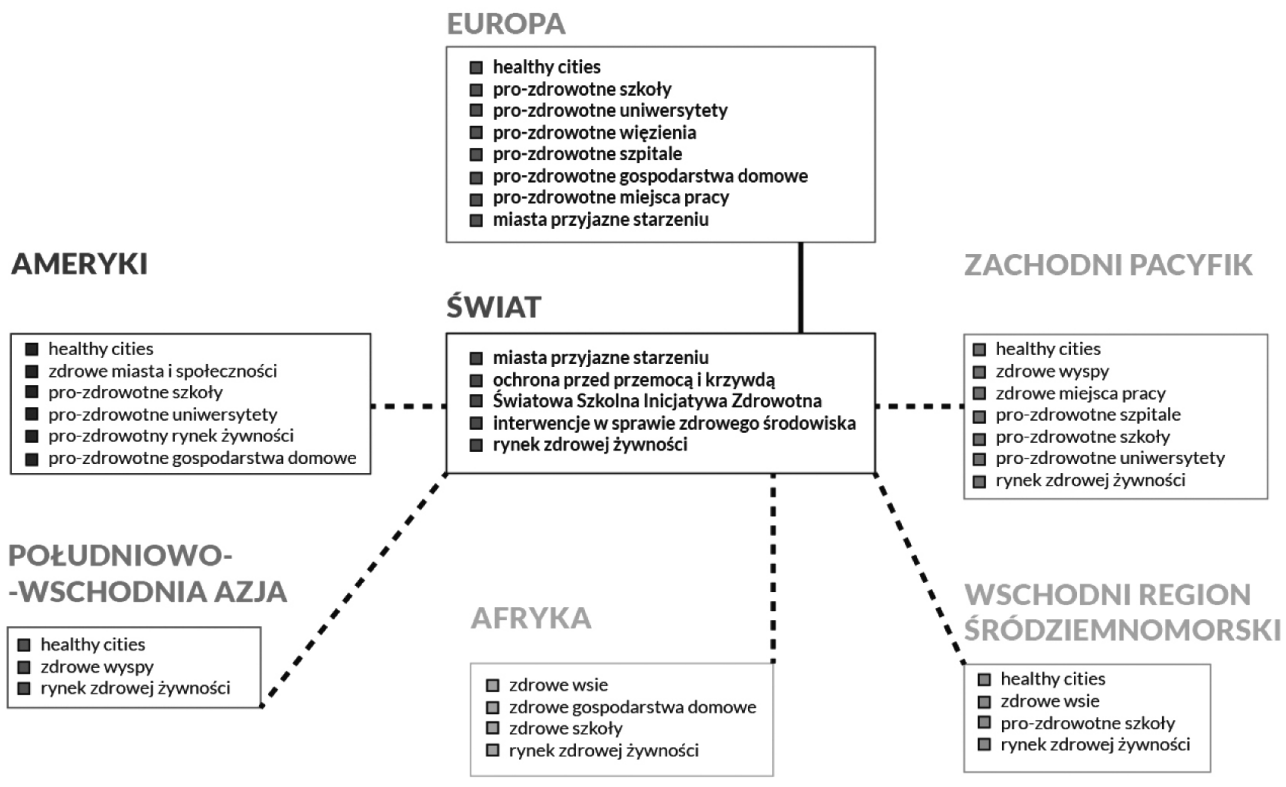

II. 2. Schemat regionalnych aktywności wdrażanych w ramach programu healthy cities (autor: Paulina Szuba, na podstawie: http://www.who.int/healthy_settings/regional/en); dostęp: 25.02.2018 


\section{PRZYPISY}

1 Poznań -fakty i liczby, www.poznan.pl/fakty_liczby (dostęp: 2.02.2018).

2 Jakość życia w Poznaniu, http://www.poznan.pl/mim/s8a/foldery-jakosc-zycia-w2-poznaniu,p,843,844,2242.html (dostęp: 2.02.2018).

3 Centrum Badania Jakości Życia, https://amu.edu.pl/dzialalnosc/badania-naukowe/centra-uniwersyteckie/centrum-badania-jakoci-ycia (dostęp: 2.02.2018).

4 Poznań-fakty i liczby, op. cit.

5 Dane z Głównego Urzędu Statystycznego, http://stat.gov.pl/ (dostęp: 1.02.2018).

6 J. Gehl, Życie między budynkami. Użytkowanie przestrzeni publicznych, Wyd. Ram, Kraków 2009.

7 Dr hab. inż. arch. Marek Czyński, prof. Zachodniopomorskiego Uniwersytetu Technicznego, prowadzi badania z zakresu: antropologii architektury, ergonomii, bezpieczeństwa behawioralnego i jakości życia w środowisku zbudowanym, terapeutycznych aspektów architektury. Autor monografii pt. Architektura w przestrzeni ludzkich zachowań. Wybrane zagadnienia bezpieczeństwa w środowisku zbudowanym, Wydawnictwo Uczelniane Politechniki Szczecińskiej, Szczecin 2006 (http://kpa.zut.edu.pl/index.php?id=9458\&no_cache=1).

8 H.M Proshansky, Environmental psychology. Man and his physical setting, Reinhart, New York 1970.

9 Evidence-based design - proces podejmowania decyzji w projektowaniu architektonicznym obiektów służby zdrowia, oparty w całości na wynikach wiarygodnych badań naukowych (dowodach). EBD jest definiowany jako wykorzystanie wiarygodnych dowodów podczas planowania i projektowania obiektów służby zdrowia dla osiągnięcia lepszych wyników hospitalizacji" (czy to cytat?)

10 R.S. Ulrich, C.M. Zimring, X. Zhu, J. DuBose, H. Seo, Y. Choi, X. Quan, A. Joseph, A review of the research literature on evidence-based healthcare design. The Center for Health Design, 2008, s. 53, http://www.healthdesign.org/hcleader/HCLeader_5_LitReviewWP. pdf (dostęp: 10.04.2014).

11 Ibidem.

12 Plan zadań badawczych WAPP na rok akademicki 2018, http://architektura.put.poznan. pl/n/wp-content/uploads/2018/01/Plan-Zada\%C5\%84-Badawczych-WAPP-na-2018.pdf) (dostęp: 12.02.2018).

13 A. Gawlak, Architektura izby przyjęć - szpital, pacjent, personel (praca doktorska).

${ }^{14}$ Projekty realizowane $\mathrm{w}$ ramach prac dyplomowych magisterskich na WAPP.

15 World Health Organization, http://www.who.int/healthy_settings/types/cities/en/ (dostęp: 27.02.2018).

16 Ibidem.

17 Health Promotion Glossary WHO/HPR/HEP/98.1, www.who.int/healthpromotion/about/ HPG/en/ (dostęp 27.02.2018). 
18 ARUP - działająca od 1946 roku międzynarodowa firma składająca się z designerów, architektów, inżynierów, konsultantów i specjalistów. Zatrudnia ponad 14 tys. pracowników w 92 biurach projektowych w 42 państwach. Oprócz bardzo rozległego dorobku inżynieryjnego (dla przykładu: Muzeum Lotnictwa Polskiego w Krakowie, Apple Park w Cupertino, Allianz Arena w Monachium) posiada solidnie zbudowany dział naukowo-badawczy, którego pracownicy prognozują stan miast w przyszłości, badają zagadnienia z dziedziny urbanistyki, energii, transportu i gospodarki wodnej.

19 ARUP, Cities Alive - Towards a Walking World, https://www.arup.com/publications/research/section/cities-alive-towards-a-walking-world (dostęp: 16.02.2018).

20 Na mocy uchwały Nr XXXIV/182/91 Rady Miasta Poznania z dnia 9 lipca 1991 r.

${ }^{21}$ Na mocy uchwały Nr XLII/452/IV/2004 Rady Miasta Poznania z dnia 27 kwietnia 2004 r.

22 Program strategiczny nr 17, s. 233, Strategia Rozwoju Miasta Poznania do roku 2030, http://www.poznan.pl/mim/s8a/attachments.html\%3Fco\%3Dshow\%26instance\%3D1011 \%26parent\%3D64566\%26lang\%3Dpl\%26id\%3D156774 (dostęp: 25.02.2018).

${ }^{23}$ Strategia Rozwoju Miasta Poznania do roku 2030 , http://www.poznan.pl/mim/s8a/attachments.html\%3Fco\%3Dshow\%26instance\%3D1011\%26parent\%3D64566\%26lang\%3 Dpl\%26id\%3D156774 (dostęp: 25.02.2018).

${ }^{24}$ Strategia Rozwoju Miasta Poznania do roku 2030, http://www.poznan.pl/mim/s8a/attachments.html\%3Fco\%3Dshow\%26instance\%3D1011\%26parent\%3D64566\%26lang\%3 Dpl\%26id\%3D156774 (dostęp: 25.02.2018).

25 Stowarzyszenie Architektów Polskich, http://poznan.sarp.org.pl/konkurs-wco-poznan/ wp-content/uploads/2018/01/OG\%C5\%81OSZENIE-konkursu.pdf (dostęp: 9.02.2018).

${ }^{26}$ Rynek Zdrowia, http://www.rynekzdrowia.pl/Inwestycje/Puszczykowo-w-szpitalu-ruszyla-budowa-bloku-operacyjnego,180874,3.html (dostęp: 2.02.2018).

27 Urbanity, http://www.urbanity.pl/wielkopolskie/poznan/blok-operacyjny-szpital-mswia,b13605 (dostęp: 2.02.2018).

28 Strategia Rozwoju Miasta Poznania do roku 2030, http://www.poznan.pl/mim/s8a/attachments.html\%3Fco\%3Dshow\%26instance\%3D1011\%26parent\%3D64566\%26lang\%3 Dpl\%26id\%3D156774 (dostęp: 25.02.2018). 


\section{BIBLIOGRAFIA}

Bańka A., Architektura psychologicznej przestrzeni życia. Behawioralne podstawy projektowania architektonicznego, Wydawnictwo Gemini, Poznań 1998.

Bańka A., Psychologiczna struktura projektowa środowiska. Studium przestrzeni architektonicznej, Wydawnictwo Politechniki Poznańskiej, Poznań 1985.

Czyński M., Architektura w przestrzeni ludzkich zachowań. Wybrane zagadnienia bezpieczeństwa w środowisku zbudowanym, Wydawnictwo Uczelniane Politechniki Szczecińskiej, Szczecin 2006.

Proshansky H.M. i in., Environmental psychology. Man and his physical setting. Reinhart, New York 1970.

Carr Valerie L., Sangiorgi D., Buscher M., Junginger S., Cooper R., Integrating Evidence-Based Design and Experience-Based Approaches in Healthcare Service Design, Herd Journal, Vol. 4, No. 4, 12-33.

Ferris T.K., Evidence-Based Design and the Fields of Human Factors and Ergonomics: Complementary Systems-Oriented Approaches to Healthcare Design, Health Environments Research \& Design Journal, Vol. 6 (3), 2013.

Gawlak A., Pruszewicz-Sipińska E., Architektura przestrzeni ogólnodostępnej w szpitalu. Pacjent i personel, Pielęgniarstwo Polskie 4/2013, Wydawnictwo Naukowe Uniwersytetu Medycznego, Poznań 2013.

Lei P., Jolibert A., A three-model comparison of the relationship between quality, satisfaction and loyalty: an empirical study of the Chinese healthcare system, BioMed Central Health Services Research, 2012, 12:436.

Mourshed M., Zhao Y., Healthcare providers' perception of design factors related to physical environments in hospitals, Journal of Environmental Psychology, 2012, 32, 362-370.

Tang L., The infuences of patient's satisfaction with medical service delivery, assessment of medical service, and trust in health delivery system on patient's life satisfaction in China, Health and Quality ol Life Outcomes, 2012, 10:111.

Gawlak A., Evidence-based design in healthcare facilities, Architecture \& Health, red. nauk. E. Pruszewicz-Sipińska, Wydawnictwo Sorus, Poznań 2015, s. 27-40.

Pruszewicz-Sipińska E., Gawlak A., Qualitative research in hospital space available to general public (ER), Architecture \& Health, red. nauk. E. Pruszewicz-Sipińska, Wydawnictwo Sorus, Poznań 2015, s. 41-52. 
Bell P.A., Greene Th.C., Fisher J.D, Baum A., Psychologia środowiskowa, Gdańskie Wydawnictwo Psychologiczne, Gdańsk 2004.

Gałkowski A.E., Pruszewicz-Sipińska E., Wąsewicz E.P., Architektoniczne, techniczno-ekonomiczne i medyczne uwarunkowania oceny stanu i koncepcji restrukturyzacji szpitali na przykładzie Regionu Wielkopolskiego, Projekt badawczy KBN nr 7TOF017 12-1999.

Głowacka M.D., Nowomiejski J., Zarzq̨zanie w ochronie zdrowia. Aktualne problemy, Polskie Towarzystwo Nauk o Zdrowiu, Poznań 2009.

Pawłowska K., Zanim wybuchnie konflikt. Idea i metody partycypacji społecznej w ochronie krajobrazu i kształtowaniu przestrzeni, praca zbiorowa pod red. K. Pawłowskiej. Fundacja Partnerstwo dla Środowiska, Kraków 2010.

Srinivas K.S., Jesus O.A., Turzo E., Marchiano A.D., Sedhev M.H., Ludmir J., Patient satisfaction with the laborist model of care in a large urban hospital, Patient Preference and Adherence, 2013, s. 217-222.

Ulrich R.S, Zimring C.M., Zhu X., DuBose J., Seo H., Choi Y., Quan X., \& Joseph A., A review of the research literature on evidence-based healthcare design, The Center for Health Design, 2008 http://www.healthdesign.org/hcleader/HCLeader_5_LitReviewWP.pdf (dostęp: 10.04.2014).

World Health Organization, http://www.who.int/healthy_settings/types/cities/en/ (dostęp 27.02.2018).

World Health Organization, http://www.euro.who.int/en/health-topics/environment-and-health/urban-health (dostęp 27.02.2018).

World Health Organization, http://www.who.int/healthpromotion/about/HPG/en/ (dostęp 27.02.2018).

Jakość życia w Poznaniu, http://www.poznan.pl/mim/s8a/foldery-jakosc-zycia-w-poznaniu,p,843,844,2242.html (dostęp: 2.02.2018).

Dane z Głównego Urzędu Statystycznego, http://stat.gov.pl/ (dostęp: 1.02.2018)

Centrum Badania Jakości Życia, https://amu.edu.pl/dzialalnosc/badania-naukowe/centra-uniwersyteckie/centrum-badania-jakoci-ycia (dostęp: 2.02.2018)

Strategia Rozwoju Miasta Poznania do roku 2030, http://www.poznan.pl/mim/s8a/attachments.html\%3Fco\%3Dshow\%26instance\%3D1011\%26parent\%3D64566\%26lang\% 3Dpl\%26id\%3D156774 (dostęp: 25.02.2018).

Stowarzyszenie Architektów Polskich, http://poznan.sarp.org.pl/konkurs-wco-poznan/wp-content/uploads/2018/01/OG\%C5\%81OSZENIE-konkursu.pdf (dostęp: 9.02.2018). 
Rynek zdrowia, http://www.rynekzdrowia.pl/Inwestycje/Puszczykowo-w-szpitalu-ruszyla-budowa-bloku-operacyjnego,180874,3.html (dostęp: 2.02.2018).

Urbanity, http://www.urbanity.pl/wielkopolskie/poznan/blok-operacyjny-szpital-mswia,b13605 (dostęp: 2.02.2018).

Harpham et al. (2001), Healthy city projects in developing countries: The first evaluation, Health Promotion International, 16(2), 111-125 (dostęp 26.02.2018).

Poznań, www.poznan.pl/fakty_liczby (dostęp 2.02.2018).

ARUP Cities Alive - Towards a walking world, https://www.arup.com/publications/research/ section/cities-alive-towards-a-walking-world, http://bip.poznan.pl/bip/uchwaly/uchwala-w-sprawie-przystapienia-miasta-poznania-do-v-fazy-projektu-zdrowe-miasta-swiatowej-organizacji-zdrowia-who,30117/ (dostęp 16.02.2018). 